\title{
Corrosion Inhibition Performance of Mild Steelusing L-Tryptophan with Sodium Potassium Tartrate in 0.1 M HCL
}

\author{
Ms.M.Priyadharshini and Dr. S. Devi Meenakshi \\ Department of Chemistry, Nadar Saraswathi College of Arts and science, Theni, India.
}

Abstract - The corrosion inhibition characteristics of nitrogen containing amino acid tryptophan (250ppm)with $0.05 \mathrm{~g}$ of SPTon mild steel in0.1M HCl, was studied by various techniques. Weight loss method analysis showed that there is an increase in inhibition efficiency by increasing the concentration of inhibitor. Polarization and impedance studies indicated that the present inhibitor system as acathodic type inhibitor. EDAX spectra confirm the presence of inhibiting elements on the metal surfaceand SEM analysis indicated the smoothness of the layer formed on the surface of the metal.

Key words: Mild steel, tryptophan, SPT, EIS, SEM, EDAX, AFM.

\section{INTRODUCTION}

'Corrosion' and 'rust' are almost synonymous terms since iron and its alloys are the most commonly used material by mankind and corrosion of iron must have been the one of the first serious corrosion problems affected humans. Most of the metals and alloys have a natural tendency to combine with water and oxygen present in its environment and return to its most stable state [1].In the last few decades, mild steel (MS) is widely applied as a constructional material in a large number of industries due to its excellent mechanical properties and it's exceptionally low cost [2, 3].Corrosion of reinforcement has been established as the predominant factor causing widespread premature deterioration of concrete construction worldwide [4]. Corrosion of bridges is a major problem of the age and requires replacement [5]. Corrosion is a cancer of metal and alloys and causes direct and indirect losses. The cost of direct loss due to corrosion has been estimated to be about 3 to $4 \%$ of GNP (Gross National Product) in developed countries. In India, the amount is calculated to be roughly $2-3 \%$ of GNP. The estimated cost of losses in India is about more than hundred crore rupees every year [6]. Corrosion inhibitors have long been used for daily operation of recirculating cooling water system, industrial acid cleaning, oil well acidification, and descaling due to their economical and efficient properties [7-9].Amino acids are nontoxic, relatively cheap, and easy to produce with purities greater than $99 \%$. Recently, with respect to amino acid as corrosion inhibitor, many achievements have been gained in laboratory studies [10-15].Almost $3 \%$ of the world's GDP is the annual cost of corrosion, because it has an impact upon the metallurgical, chemical, oil industries and so on. In addition, governments and industries pay little attention to corrosion except in large risk areas such as aircraft and pipelines [16-18]. The amino acids which contain carboxyl and amino functionalities bonded to the same carbon atom are non-toxic, relatively cheap and easy to produce in purities greater than $99 \%$ [19-21]. The high efficiency of organic compounds as corrosion inhibitors is due to the polar functions from the presence of $\mathrm{S}, \mathrm{O}$, or $\mathrm{N}$ atoms, which are used as centers to establish the adsorption process $[22,23,24,25,26]$. Hence, the present system (Ltryptophan with Sodium Potassium tartrate) consisting the hetero atoms present in theshows their corrosion inhibition performance in acid medium.

\section{MATERIALS AND METHODS}

The Mild steel specimens were chosen from the same sheet of the following composition: Carbon - $0.1 \%$, Sulphur $0.026 \%$, Phosphorus - $0.06 \%$, Manganese $-0.4 \%$ and the balance iron. Mild steel specimen of the dimension $3 \times 2 \times 0.2 \mathrm{~cm}$ were polished to mirror finish, degreased with 
acetone and used for mass - loss and surface examination studies.

\section{Electrochemical studies:}

\section{Potentiodynamic polarization study:}

Polarization and AC impedance study was carried out in Electrochemical Impedance analyzer model CHI 660A three electrode cell assembly was used. The working electrode was used as a rectangular specimen of mild steel with one face of the electrode of constant $1 \mathrm{~cm}^{2}$ area exposed. A saturated calomel electrode (SCE) was used as the reference electrode and a rectangular platinum foil was used as the counter electrode. Polarization curves were recorded after doing ire compensation. The corrosion parameters such as corrosion potential (Icorr), corrosion current (Icorr) and Tafel slopes (anodic $=\mathrm{b}_{\mathrm{a}}$ and cathodic $=b_{c}$ ) and Linear polarization resistance (LPR) were calculated. During the polarization study, the scan rate $(\mathrm{V} / \mathrm{s})$ was 0.005; Hold time at Eve(s) was zero and quite time (s) was 2.Cdl values were calculated using the following relationship.

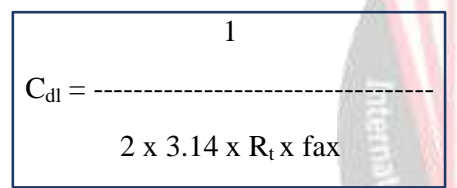

Scanning Electron Microscopic studies (SEM) and EDX:

The mild steel specimen immersed in blank and in the inhibitor solution for a period of one day was removed, rinsed with double distilled water, dried and observed in a scanning electron microscope to examine the surface morphology. The surface morphology measurements of the mild steel were examined using Tescon, Vega3, and USA computer controlled scanning electron microscope. The elemental analysis of the mild steel surface at the same condition was carried out using an energy dispersive X-ray analyzer (EDAX) [Brucker, Nano, GMBH, Germany] unit attached to the SEM machine.

\section{Atomic Force Microscopy characterization (AFM):}

The mild steel specimen immersed in blank and in the inhibitor solution for a period of one day was removed, rinsed with double distilled water, dried and subjected to the surface examination. The surface morphology measurements of the mild steel surface were carried out by atomic force microscopy (AFM) using Pico SPM 9500-21 with the software version of Pico scan version 5.4

\section{RESULT AND DISCUSSION}

\section{Analysis of results of the weight loss method}

The corrosion rates and the inhibition efficiencies(IE) of L-tryptophan(AA) and L-tryptophan withSodium Potassium tartrate(SPT) in controlling corrosion of mild steel immersed in $0.1 \mathrm{M}$ HClfor a period of one day in the absence of and presence of inhibitors is given in Table1.

Table1. Inhibition efficiencies (IE\%) and corrosion rates (CR) obtained from AA-SPT system in controlling corrosion of mild steel immersed in $0.1 \mathrm{M} \mathrm{HCl}$

Inhibitor system: AA + SPTin $0.1 \mathrm{M} \mathrm{HCl}$ Immersion period: 1 day

\begin{tabular}{|c|c|c|}
\hline Electrolytic solution & $\begin{array}{c}\text { Corrosion } \\
\text { rate } \mathrm{mg} \mid \mathrm{cm}^{2}\end{array}$ & $\begin{array}{l}\text { Inhibition } \\
\text { efficiency \% }\end{array}$ \\
\hline $0.1 \mathrm{MHCl}$ (Blank) & 0.22 & 77.5 \\
\hline $50 \mathrm{ppm} \mathrm{AA}+0.05 \mathrm{~g} \mathrm{SPT}$ in $0.1 \mathrm{MHCl}$ & 0.19 & 85.6 \\
\hline $\begin{array}{l}150 \mathrm{ppm} \text { AA }+0.05 \mathrm{~g} \text { SPT in } \\
0.1 \mathrm{MHCl}\end{array}$ & 0.17 & 87.4 \\
\hline $\begin{array}{l}250 \mathrm{ppm} \mathrm{AA}+0.05 \mathrm{~g} \mathrm{SPT} \text { in } \\
0.1 \mathrm{MHCl}\end{array}$ & 0.15 & 89.2 \\
\hline
\end{tabular}

It is observed from Table 2 that L-tryptophan shows some inhibition efficiency. After the addition of L-tryptophan in different concentrationswith $0.05 \mathrm{~g}$ SPT in $0.1 \mathrm{MHCl}$ the inhibition efficiency increases. 50ppm of AA $+0.05 \mathrm{~g}$ SPT in $0.1 \mathrm{MHClhas} 85.6 \%, 150 \mathrm{ppm}$ of $\mathrm{AA}+0.05 \mathrm{~g}$ SPT in $0.1 \mathrm{MHCl}$ has $87.4 \%$ and $250 \mathrm{ppm}$ of $\mathrm{AA}+0.05 \mathrm{~g} \mathrm{SPT}$ in $0.1 \mathrm{MHCl}$ has $89.2 \%$. That is addition of inhibitor system in $0.1 \mathrm{M}$ HClincreases the corrosion protection of mild steel immersed in the solution. That is, the system passes from active to passive region.

\section{ANALYSIS OF POTENTIODYNAMIC POLARIZATION STUDY}

Electrochemical study such as Polarization study has been used to confirm the formation of protective film on the metal surface during corrosion inhibition process. If a 
protective film is formed on the metal surface, the linear polarization resistance values (LPR) increases and the corrosion current value $\left(\mathrm{I}_{\text {corr }}\right)$ decreases.

The potentiodynamic polarization curves of mild steel immersed in $0.1 \mathrm{M} \mathrm{HCl}$ in the absence and presence of inhibitor are shown in Fig 1. The corrosion parameters namely, corrosion potential $\left(\mathrm{E}_{\mathrm{corr}}\right)$, Tafel slopes (anodic slope $b_{a}$ and cathodic slope $b_{c}$ ) Linear polarization resistances (LPR) and corrosion current $\left(\mathrm{I}_{\text {corr }}\right)$ values are given in the Table 2 .

When mild steel is immersed in $0.1 \mathrm{M} \mathrm{HCl}$ the corrosion potential was-0.5190mVvs SCE (saturated calomel electrode). When $\mathrm{AA}(50 \mathrm{ppm})+0.05 \mathrm{~g}$ SPTwas added it shifted to $-0.3684 \mathrm{mV}$ when AA (150ppm)+0.05g SPTwas added it shifted to $-0.3373 \mathrm{mV}$ when AA (250ppm)+0.05g SPTwas added it shifted to $-0.3271 \mathrm{mVVs}$ SCEthat is cathodic side as noble side. This indicates that the AA+SPT system controls cathodic reaction predominantly. This indicates that the passive film is formed on the metal surface in presence of inhibitor. Further, the LPRvalue increases When a passive film is formed on mild steel surface, in presence of inhibitor system, the electron transfer from the metal surface towards the bulk of the solution is difficult and prevented. So rate of corrosion decreases and hence corrosion current decreases in presence of inhibitor system.

Table 2:Corrosion parameters of mild steel immersed in 0.1M HCl in the absence and presence of AA + SPT system obtained from Potentiodynamic Polarization Study

\begin{tabular}{|c|c|c|c|c|c|}
\hline System & $\begin{array}{c}\mathbf{E}_{\text {corr }} \\
\mathbf{m V} \text { vs } \\
\text { SCE }\end{array}$ & $\begin{array}{l}b_{c} m V / \\
\text { decade }\end{array}$ & $\begin{array}{c}\mathbf{b}_{\mathrm{a}} \\
\mathrm{mV} / \\
\text { decade }\end{array}$ & $\underset{\text { ohmcm }}{\text { LPR }}$ & $\mathbf{I}_{\text {corr }} \mathbf{A c m}^{-2}$ \\
\hline $0.1 \mathrm{MHCl}$ (Blank) & -0.5190 & 4.733 & 3.730 & 15.9 & $\begin{array}{c}0.03232 \times 10 \\
6\end{array}$ \\
\hline $\begin{array}{l}50 \mathrm{ppm} \mathrm{AA} \mathrm{+} \\
0.05 \mathrm{~g} \quad \text { SPTin } \\
0.1 \mathrm{MHCl}\end{array}$ & -0.3684 & 5.561 & 3.670 & 2420.8 & $\begin{array}{c}0.01946 \times 10 \\
6\end{array}$ \\
\hline $\begin{array}{l}150 \mathrm{ppm} \mathrm{AA} \mathrm{+} \\
0.05 \mathrm{~g} \quad \mathrm{SPT} \quad \text { in } \\
0.1 \mathrm{MHCl}\end{array}$ & -0.3373 & 6.288 & 3.38205 & 2593.9 & $\begin{array}{c}0.01733 \times 10 \\
6\end{array}$ \\
\hline $\begin{array}{l}250 \mathrm{ppm} \mathrm{AA+} \\
0.05 \mathrm{~g} \quad \mathrm{SPT} \quad \text { in } \\
0.1 \mathrm{MHCl}\end{array}$ & -0.3271 & 6.204 & 4.153 & 33501 & $\begin{array}{c}0.01253 \times 10 \\
6\end{array}$ \\
\hline
\end{tabular}

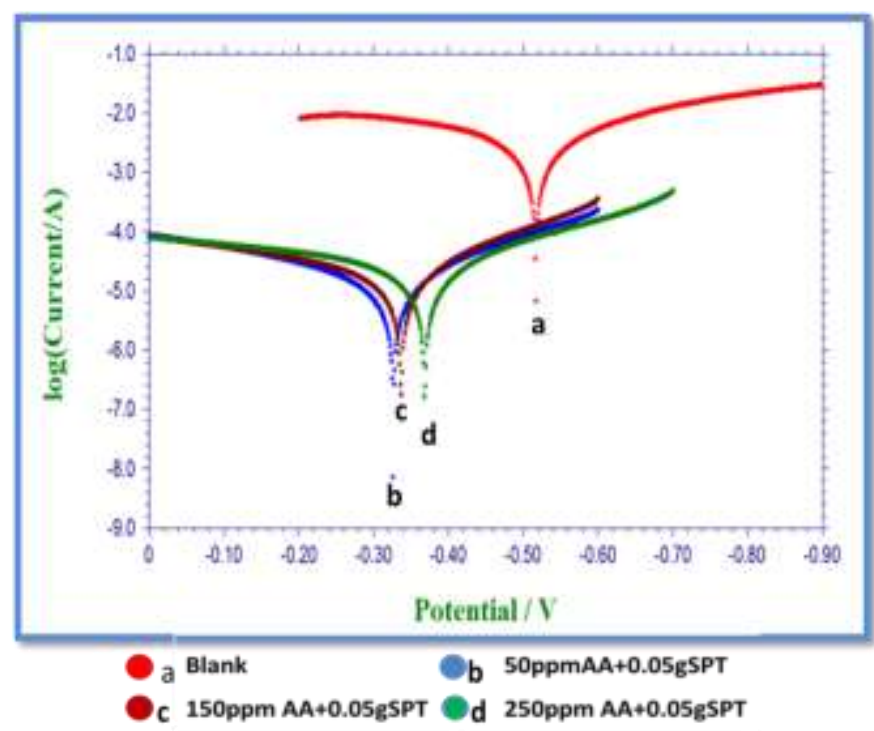

Fig 1.Polarization curves of mild steel immersed in various test solutions(Blank，50ppmAA+SPT, 150ppm

$\mathrm{AA}+\mathrm{SPT}, 250 \mathrm{ppm} \mathrm{AA}+\mathrm{SPT}$ ) prepared in $0.1 \mathrm{MHCl}$

3. Analysis of AC impedance spectra:

AC impedance spectra (electro chemical impedance spectra) have been used to confirm the formation of protective film formed on the metal surface. If a protective film on the metal surface, the charge transfer resistance $\left(R_{t}\right)$ increases, double layer capacitance value $\left(\mathrm{C}_{\mathrm{dl}}\right)$ decreases and the impedance $\log (\mathrm{z} / \mathrm{ohm})$ value increases. The AC impedance spectra of mild steel immersed in $0.1 \mathrm{MHCl}$ in the absence and presence of inhibitor are shown as Nyquist plotin Fig 2, and Bode plots in Fig 3, Fig 4, Fig 5 and in Fig 6.The AC impedance parameters such as charge transfer resistance $\left(R_{t}\right)$,double layer capacitance $\left(C_{d l}\right)$ and impedance value $\log (\mathrm{z} / \mathrm{ohm})$ are given in table 3 .

Table 3: Impedance parameters of mild steel immersed in0.1M $\mathrm{HCl}$ in the absence and presence of inhibitor system obtained from AC impedance spectra

\begin{tabular}{|l|c|c|c|}
\hline \multirow{2}{*}{ System } & \multicolumn{2}{|c|}{ Nyquist plot } & Bode plot \\
\cline { 2 - 4 } & $\begin{array}{c}\mathbf{R}_{\mathbf{t}} \\
\text { ohm } \mathbf{~ c m}^{2}\end{array}$ & $\begin{array}{c}\mathbf{C}_{\text {dl }} \\
\text { F/cm }\end{array}$ & $\begin{array}{c}\text { Impedance value } \\
\text { log (z/ohm) }\end{array}$ \\
\hline $0.1 \mathrm{MHCl}($ Blank) & 11.79 & $4.24 \times 10^{-9}$ & 1.2 \\
\hline 50ppmAA+SPT in 0.1MHCl & 401.62 & $7.55 \times 10^{-9}$ & 2.7 \\
\hline 150ppmAA+SPT in 0.1MHCl & 410.48 & $1.24 \times 10^{-9}$ & 2.8 \\
\hline 250ppmAA+SPT in 0.1MHCl & 662.19 & $1.22 \times 10^{-9}$ & 2.9 \\
\hline
\end{tabular}


The Nyquist plots obtained comprise of the depressed semicircle, which indicates that the steel dissolution is essentially a charge transfer process [27, 28]. The size of the Nyquist plots rises with respect to the blank solution and with increasing inhibitor concentration signifying that the AA+SPT system formed an inhibitor film on the mild steel surface. Moreover, it is observed that when mild steel is immersed in $0.1 \mathrm{M} \mathrm{HCl}, \mathrm{R}_{\mathrm{t}}$ is $11.79 \mathrm{ohmcm}^{2}$ and $\mathrm{C}_{\mathrm{dl}}$ value is $4.24 \times 10^{-9} \mathrm{~F} / \mathrm{cm}^{2}$. When mild steel isimmersed in $0.1 \mathrm{M}$ $\mathrm{HCl} \mathrm{R}_{\mathrm{t}}$ values increases and the $\mathrm{C}_{\mathrm{dl}}$ value decreases as indicated in the table.3. The impedance $\log (\mathrm{z} / \mathrm{ohm})$ value increases gradually as the concentration of increased inhibitor concentration asfrom 1.2 to 3.2, 3.5, and 3.6.This suggests that a protective film is formed on the metal surface.

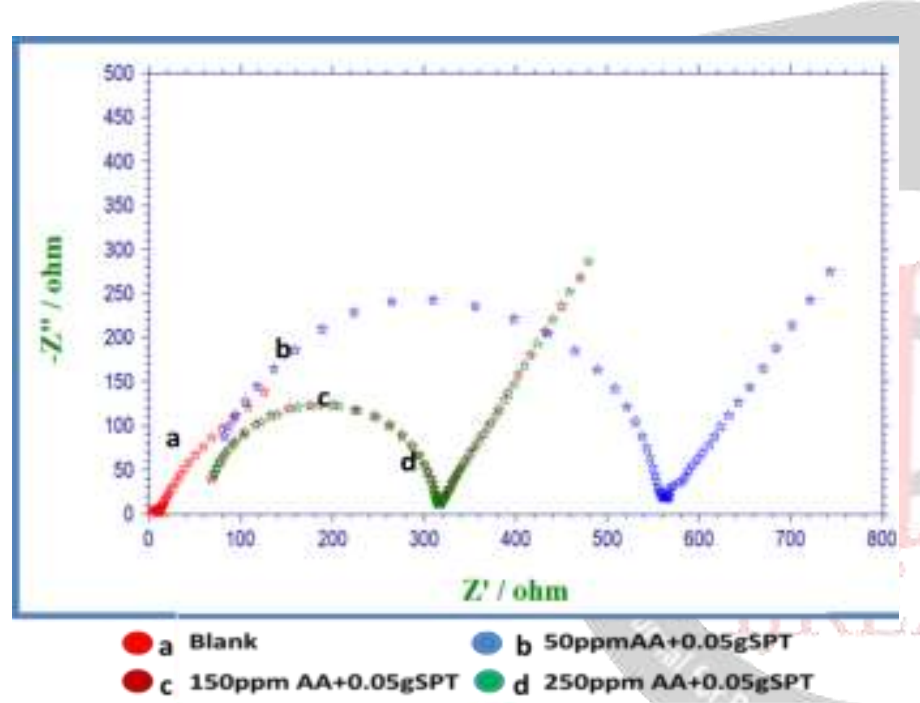

Fig 2.AC impedance spectra-Nyquist plots of mild steel immersed in various test solutions

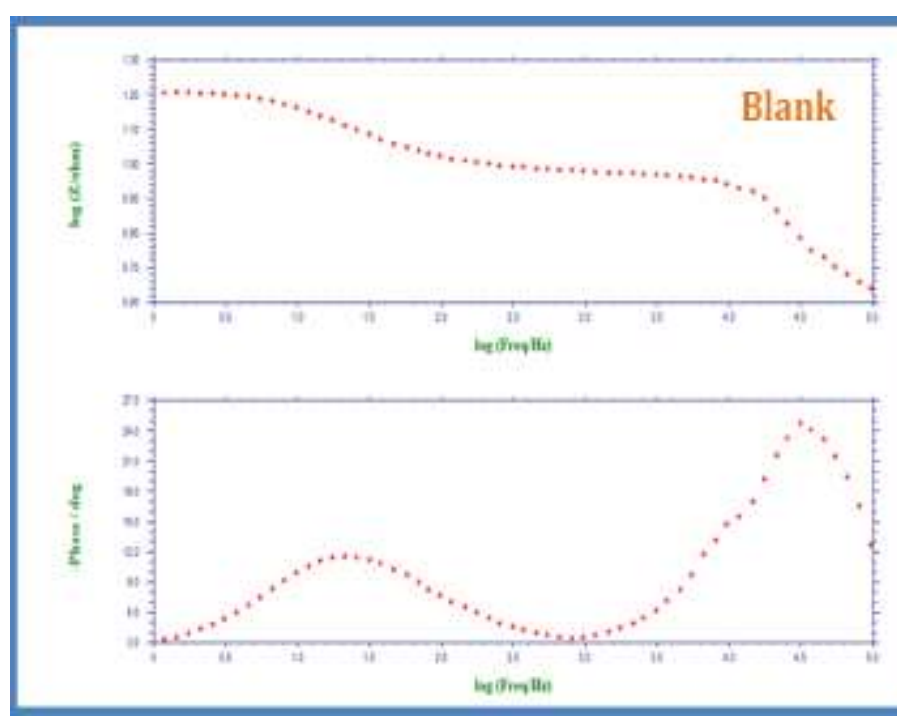

Fig 3.AC impedance spectra-Bode plot of $0.1 \mathrm{M}$ HCl(Blank) solution

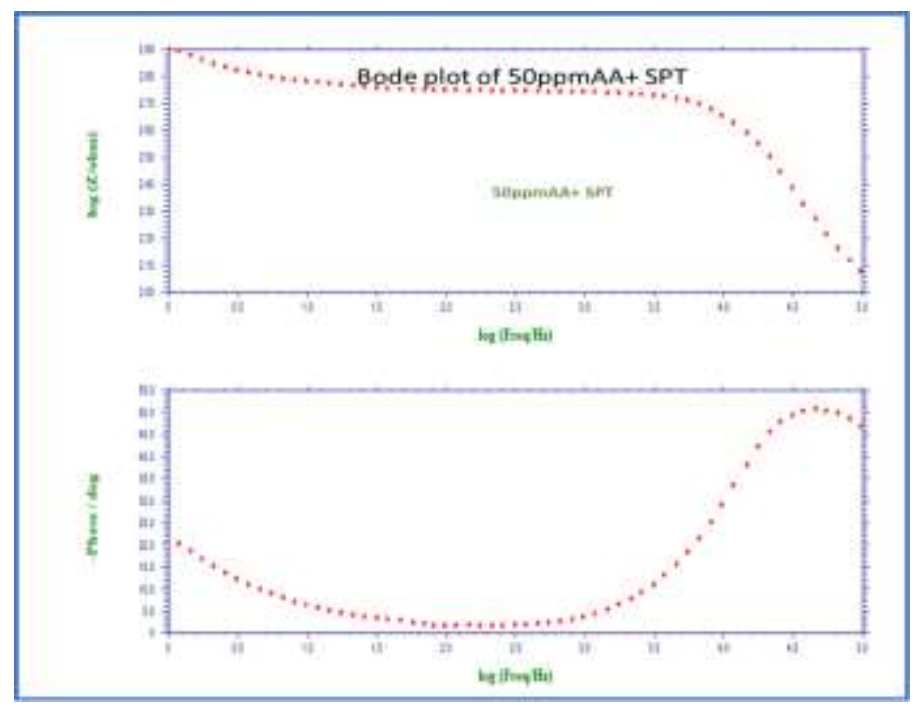

Fig 4.AC impedance spectra-Bode plot of 50ppm AA+ SPT in 0.1M HCl (Blank) solution

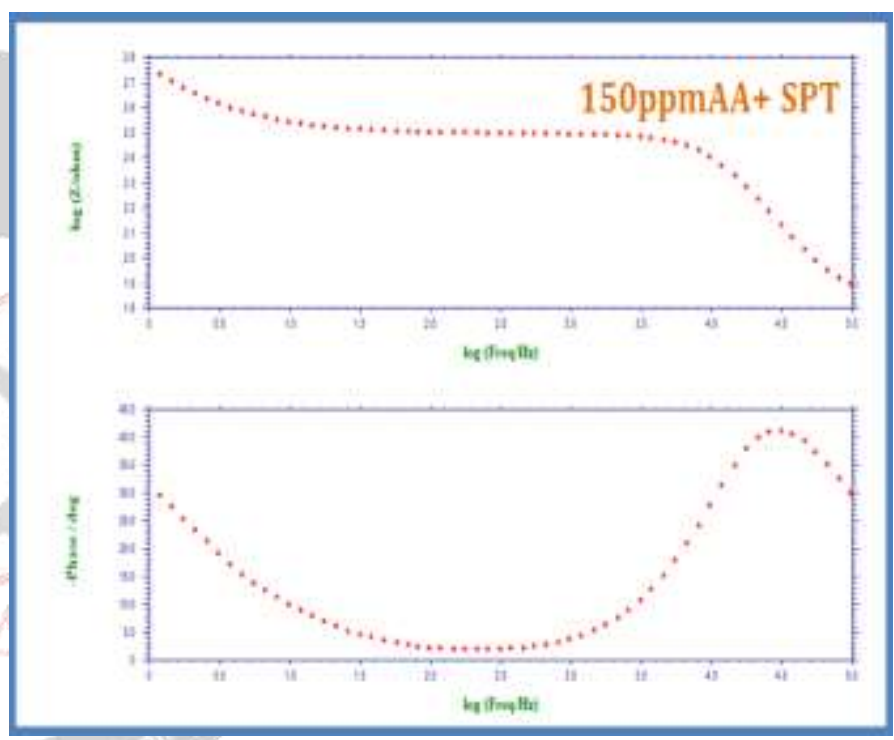

Fig 5.AC impedance spectra- Bode plot of 150ppm $\mathrm{AA}+$ SPT in 0.1M HCl (Blank) solution

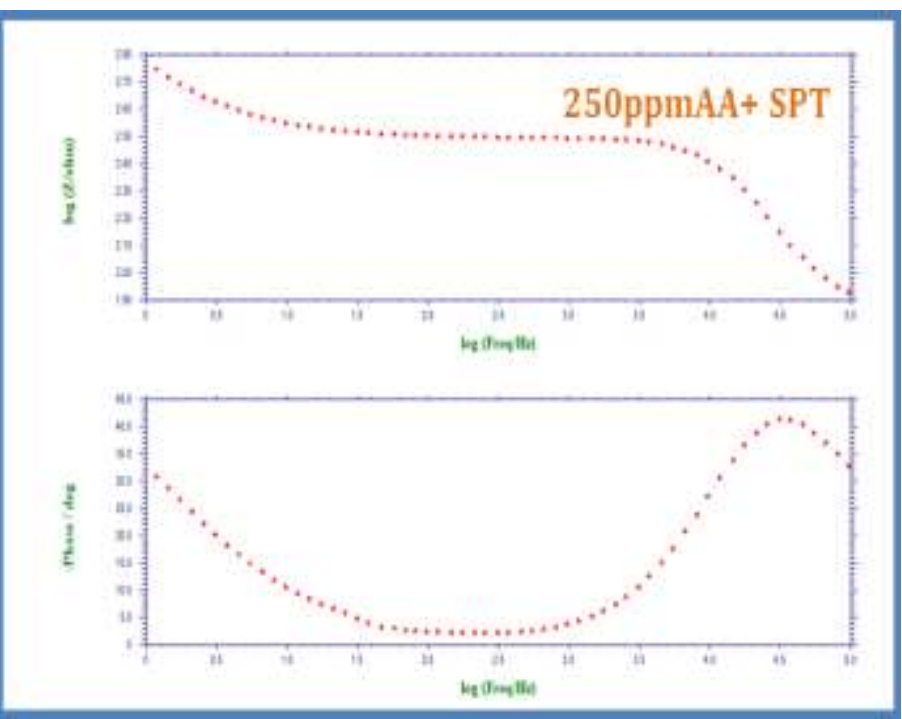

Fig 6.AC impedance spectra-Bode plot of 250ppm $\mathrm{AA}+$ SPT in 0.1M HCl (Blank) solution 


\section{SEM Analysis OF Metal SuRfaCe}

SEM provides a pictorial representation of the surface. To understand the nature of the film in the absence and

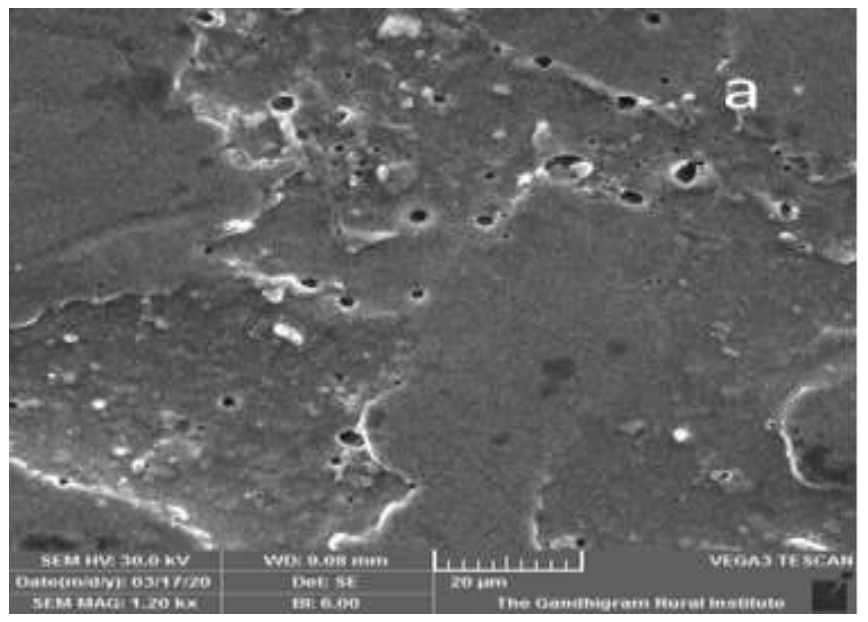

presence of inhibitors and the extent of corrosion of mild steel, the SEM microscopes of the surface are examined.

Fig 7.SEM micrographs of mild steel immersed in0.1M HCl(Blank); Magnifications X20(a),X50(b)
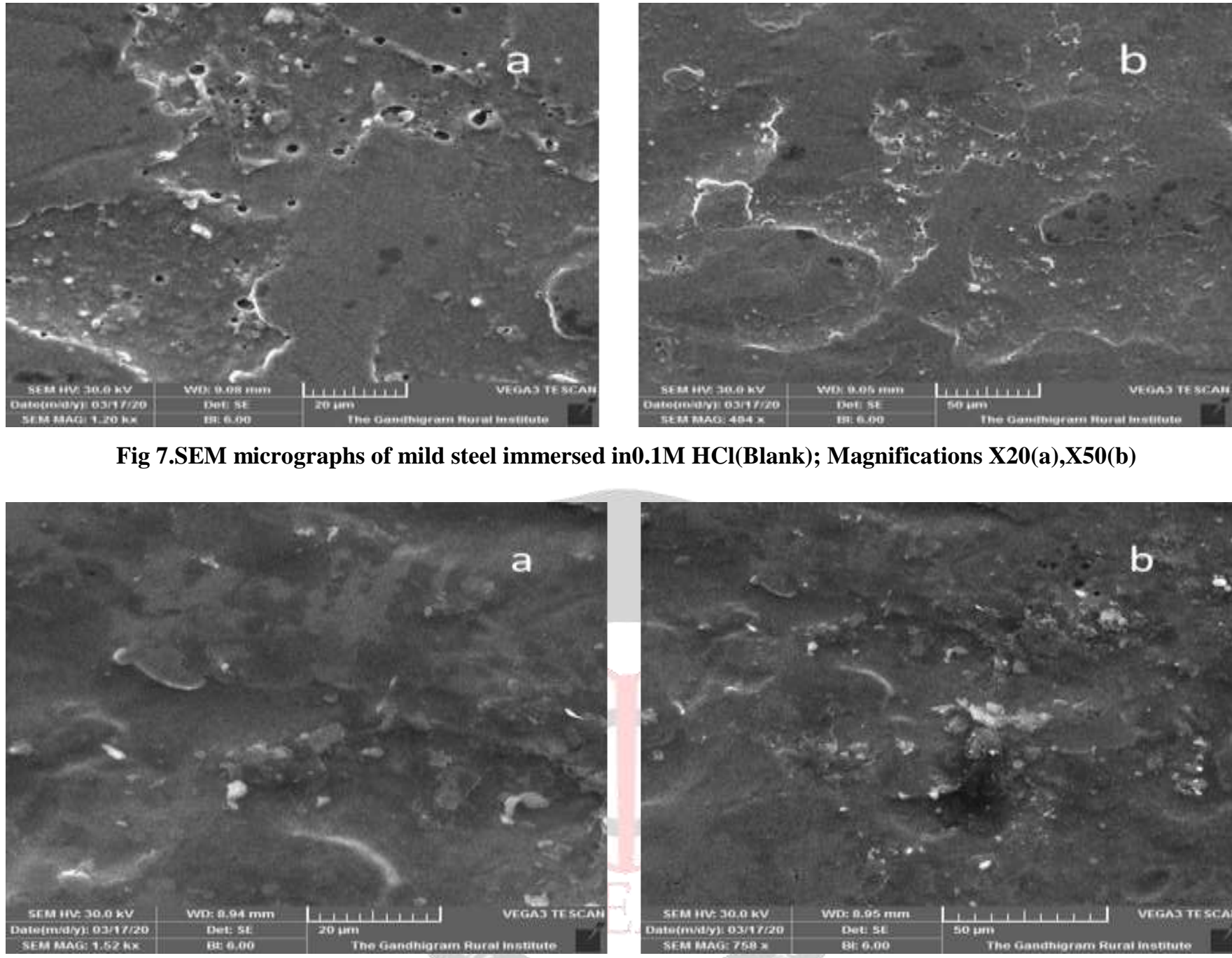

\section{Fig 7.SEM micrographs of mild steel immersed in0.1M HC(Blank), Magniflcations X20(a),X50(b)}

Fig 8.SEM micrographs of mild steel immersed in 250ppm AA+ 0.05g SPTin0.1M HCl; Magnification X20(a),X50(b)

The SEM images of different magnifications (X20, X50) of mild steel specimen immersed in blank and 250ppmAA+SPT in 0.1MHClfor 1 day are shown in Fig.7 (a,b) and Fig.8 ( a,b) respectively.

The SEM micrographs of different magnifications of mild steel surface immersed in $0.1 \mathrm{M} \mathrm{HCl}$ in Fig. $7(a, b)$ shows the roughness of the metal surface which indicates the highly corroded area on mild steel and Fig.8 (a,b)shows the smoothness of the metal surface which indicates the formation of protective film on the metal surface.

5. Surface analysis - Energy dispersive analysis of $X$ rays (EDAX)

The EDAX spectra were used to determine the elements present on the metal surface before and after exposure to the inhibitor solution. EDAX examinations of the mild steel

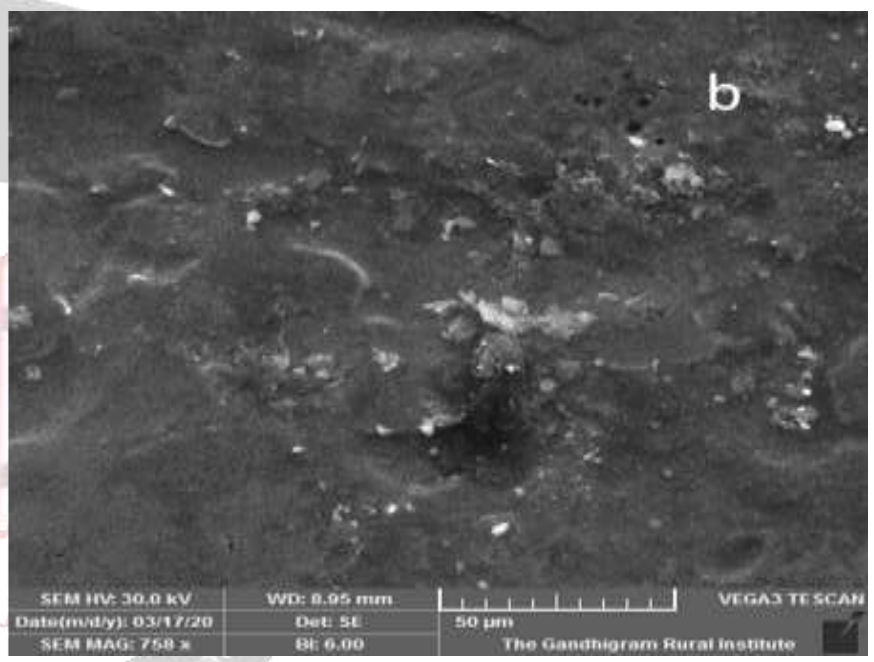
surface were performed in blank and 250ppmAA+SPT in 0.1MHClfor 1 day are shown in Fig.9 to Fig.10respectively.

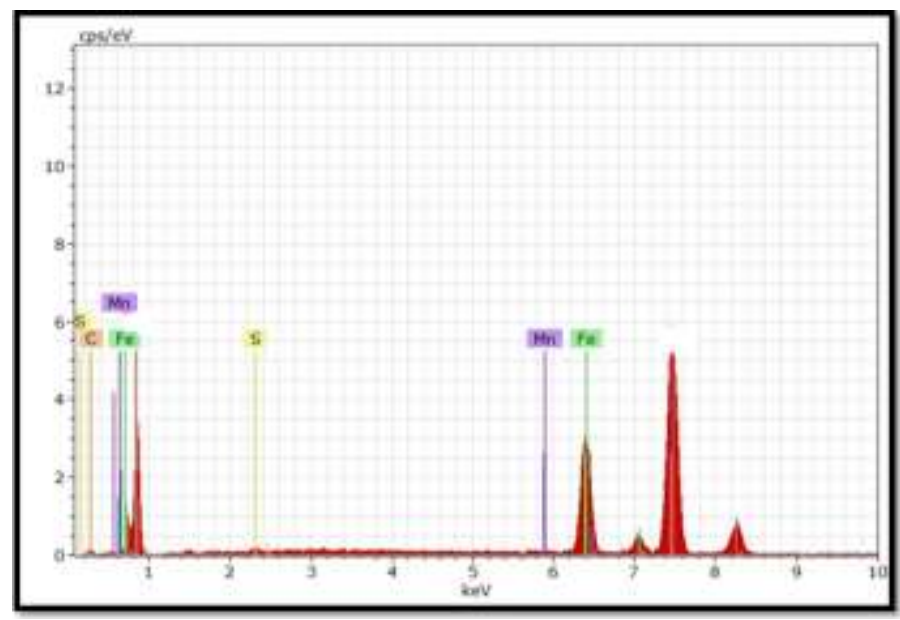

Fig.9: EDAX spectra of mild steel specimen in $0.1 \mathrm{M} \mathrm{HCl}$ (Blank) 


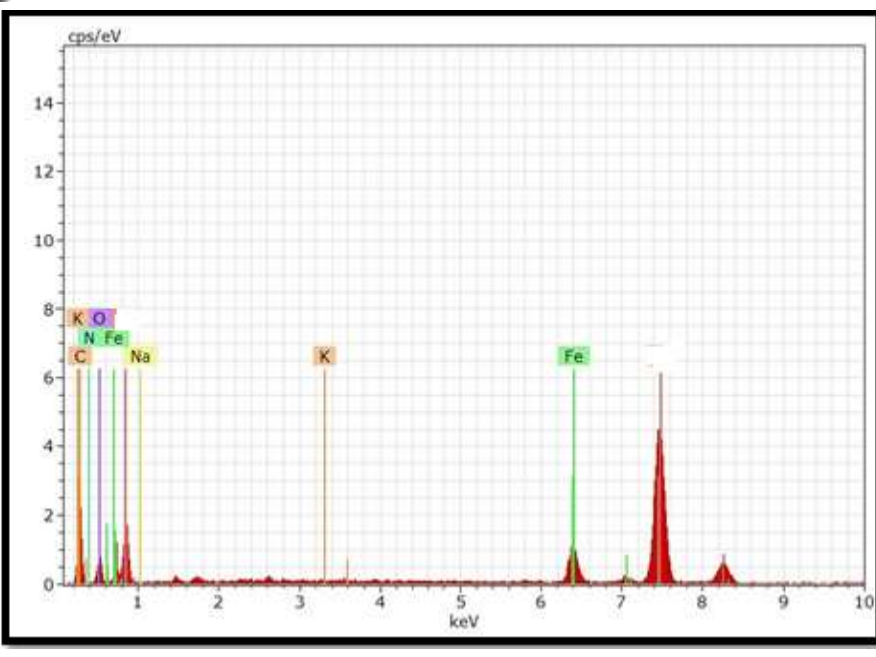

Fig.10: EDAX spectra of mild steel immersed in 250ppm

\section{$\mathrm{AA}+0.05 \mathrm{~g}$ SPT in $0.1 \mathrm{M} \mathrm{HCl}$}

The analysis shows the presence of $(\mathrm{Na}, \mathrm{K})$ peak, [where there is no presence of $\mathrm{Na}$ and $\mathrm{K}$ on mild steel surface in blank solution] this concludes the presence of sodium and potassium on the metal surface and notable decrease in iron peak shows the formation of protective film on the metal surface. The surface of mild steel sample is preserved to a large extent due to formation of the protective film formed of the inhibitor molecules as indicated by the decrease of ionization energy.

\section{Surface ANALYSIS - Atomic Force MICROSCOPY}

Atomic force microscopy is a powerful technique for gathering roughness statistics from a variety of surfaces. AFM is becoming an accepted method of roughness iron peak in Fig:10. This leading to a high degree of

investigation. The two dimensional (2D), three dimensional (3D) AFM morphologies, AFM cross - sectional profile and histogram images of surface for of the mild steel surface were performed in blank and in 250ppmAA+SPT in $0.1 \mathrm{MHCl}$ system for 1 day are shown in Fig.11 and in Fig. 12 respectively.

Root - mean - square roughness, average roughness and peak - to - valley value for SPT system

AFM image analysis was performed to obtain the average roughness, $\mathrm{R}_{\mathrm{a}}$ (the average deviation of all points roughness profile from a mean line over the evaluation length), root mean - square roughness, $\mathrm{R}_{\mathrm{q}}$ (the average of the measured height deviations taken within the evaluation length and measured from the mean line)and the maximum peak- to valley $(\mathrm{P}-\mathrm{V})$ height values (largest single peak - to - valley height in five adjoining sampling heights). $\mathrm{R}_{\mathrm{q}}$ is much more sensitive than $\mathrm{R}_{\mathrm{a}}$ to large and small height deviations from the mean.

Table - 5 AFM data for mild steel surfaces immersed in inhibited and uninhibited environments

\begin{tabular}{|l|c|c|c|}
\hline $\begin{array}{c}\text { System } \\
\text { (Mild Steelimmersed } \\
\text { in) }\end{array}$ & $\begin{array}{c}\text { Average }\left(\mathbf{R}_{\mathbf{a}}\right) \\
\text { Roughness } \\
(\mathbf{n m})\end{array}$ & $\begin{array}{c}\text { RMS(R }\left(\mathbf{R}_{\mathbf{q}}\right) \\
\text { Roughness } \\
(\mathbf{n m})\end{array}$ & $\begin{array}{c}\text { Maximum } \\
\text { peak }-\mathbf{t o}- \\
\text { valley height } \\
(\mathbf{n m})\end{array}$ \\
\hline Blank & 669.81 & 884.15 & 1.84 \\
\hline $\begin{array}{l}\text { 250ppmAA+SPT } \\
\text { in 0.1MHCl }\end{array}$ & 186.32 & 253.25 & 1.62 \\
\hline
\end{tabular}
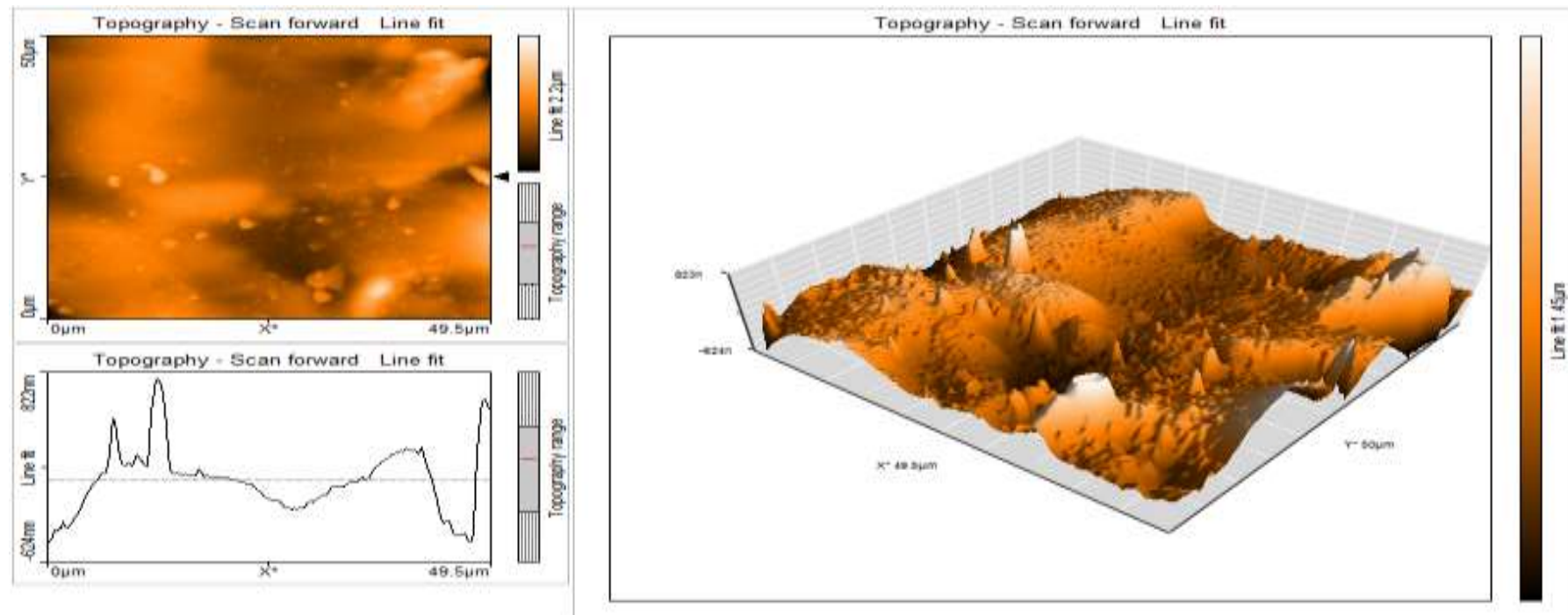

Fig 25. AFM image of mild steel specimen in 0.1M HCl (Blank) 


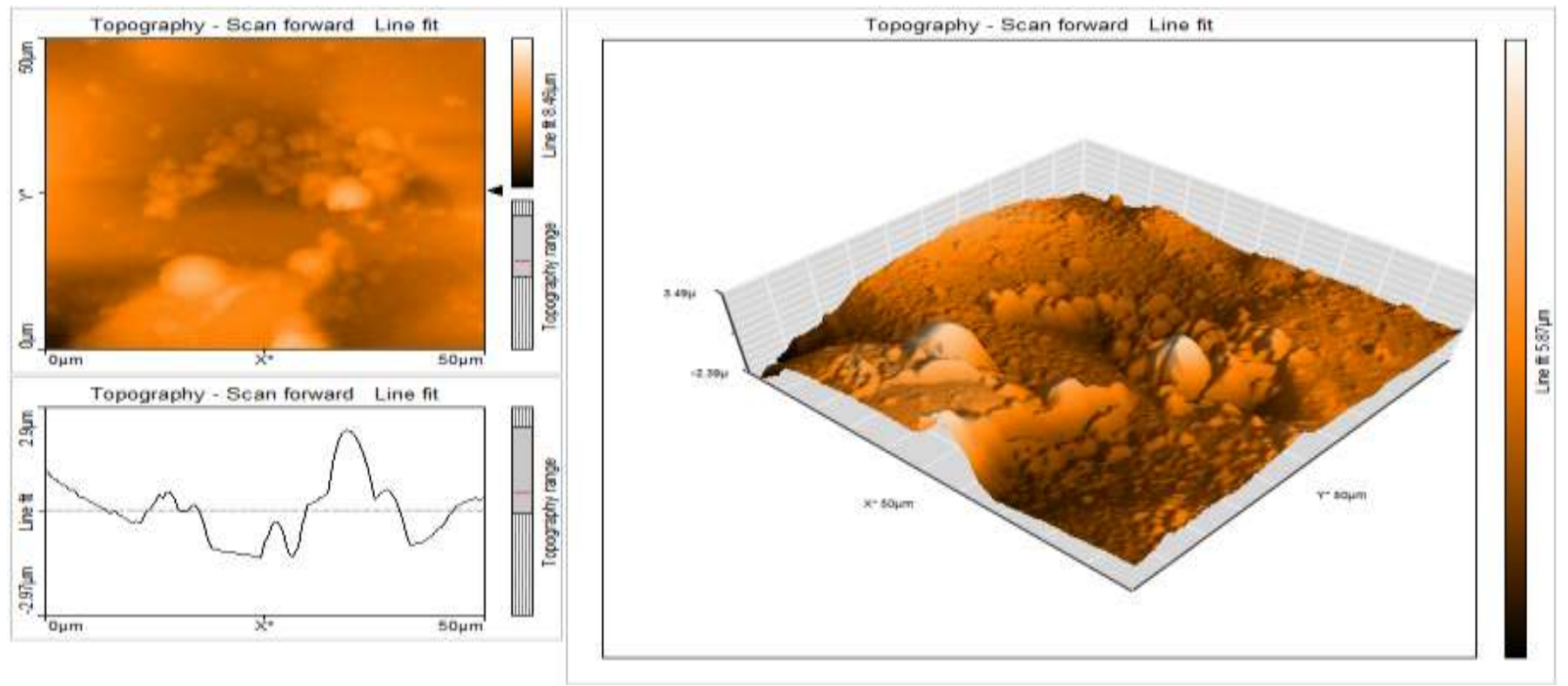

Fig 26AFM image of mild steel immersed in 250ppm AA+ 0.05g SPT in 0.1M HCl

Table -5 is the summary of the average roughness $\left(R_{a}\right)$, rms roughness $\left(\mathrm{R}_{\mathrm{q}}\right)$ maximum peak- to- valley height $(\mathrm{P}-\mathrm{V})$ value for mild steel surface immersed in different environments. The value of $\mathrm{R}_{\mathrm{a}}, \mathrm{R}_{\mathrm{RMS}}$ and peak to valley height for the mild steel immersed in $0.1 \mathrm{M} \mathrm{HCl}$ are669.81, 884.15 and 1.84shown in Fig.25. The slight roughness observed on the mild steel surface is due to atmospheric corrosion. These data suggest that mild steel surface immersed in $0.1 \mathrm{M} \mathrm{HCl}$ displays the corroded metal surface with few pits.The presence of mild steel immersed in $0.1 \mathrm{M}$ $\mathrm{HCl}$ and $250 \mathrm{ppm}$ of $\mathrm{AA}+0.05 \mathrm{~g}$ SPT reduces the $\mathrm{R}_{\mathrm{av}}$ by a factor of $186.32 \mathrm{~nm}$ from $669.81 \mathrm{~nm}$ and the RMS roughness is significantly reduced to $253.25 \mathrm{~nm}$, when compared with $884.15 \mathrm{~nm}$ of mild steel surface immersed in $0.1 \mathrm{M} \mathrm{HCl}$. The maximum peak to valley height also reduced to $1.62 \mathrm{~nm}$ from $1.84 \mathrm{~nm}$. These parameters confirm that the surface appears smoother. The smoothness of the surface is due to the formation of a compact protective film of $\mathrm{Fe}^{2+}-\mathrm{SPT}$ complex and AA on the metal surface thereby inhibiting the corrosion of mild steel, also the above parameters are observed somewhat greater than the AFM data of polished metal surface, which confirms the formation of the film on the metal surface, which is protective in nature.

\section{CONCLUSION}

The corrosion study of amino acid in the presence of Sodium Potassium tartrate has revealed that the inhibition efficiency tended to increase with increasing inhibitor concentration. Polarization measurements show that they are cathodic-type inhibitors. Nyquist plots established that the inhibitors reduced the mild steel corrosion through their effective adsorption of inhibitive layer, which is further evidenced from SEM and AFM. From the above studies we are reported that $250 \mathrm{ppm}$ of amino acid in the presence of Sodium Potassium tartrate as a best corrosion inhibitor for Mild Steel corrosion in $0.1 \mathrm{MHCl}$ solution.

\section{REFERENCES}

[1]. M.R Ezhilarasi, B.Prabha, T. Santhi, Res. J. Chem. Sci., 2015.5, 1-2

[2].M. Yadav, L. Gope, N. Kumari, and P. Yadav, "Corrosion inhibition performance of pyranopyrazole derivatives for mild steel in $\mathrm{HCl}$ solution: gravimetric, electrochemical and DFT studies," Journal of Molecular Liquids, vol. 216, pp. 78-86, 2016.

[3].M. E. Mashuga, L. O. Olasunkanmi, and E. E. Ebenso, "Experimental and theoretical investigation of the inhibitory effect of new pyridazine derivatives for the corrosion of mildsteel in $1 \mathrm{M} \mathrm{HCl}$," Journal of Molecular Structure, vol. 1136, pp. 127-139, 2017.

[4]. M.Raupauch and P. Schie\& NDT\&EInt(84) (2001) 435

[5]. FouadBentissa, MounimLebrinia, HervéVezinb, Michel Lagrenéea,* received in revised form 10 April 2004; accepted 22 May 200 
[6]. Camila G. Dariva and Alexandre

F.Galiohttp://dx.doi.org/10.5772/57255

[7]. Demadis KD, Mavredaki E, Stathoulopoulou A, Neofotistou E, Mantzaridis C (2007) Desalination 213:38

[8]. Behpour M, Ghoreishi SM, Gandomi-Niasar A, Soltani N, Salavati-Niasari M (2009) J Mater Sci 44(10):2444. doi:10.1007/ s10853-009-3309-y

[9]. El-Meligi AA, Turgoose S, Ismail AA, Sanad SH (2000) Br Corros J 35(1):75

[10]. Badawy WA, Ismail KM, Fathi AM (2006) ElectrochimActa 51(20):4182

[11]. Morad MS (2008) J ApplElectrochem 38(11):1509

[12]. Olivares O, Likhanova NV, Go 'mez B, Navarrete J, Llanos-Serrano ME, Arce E, Hallen JM (2006) Appl Surf Sci 252(8):2894

[13]. Olivares-Xometl O, Likhanova NV, Domı 'nguezAguilar MA, Arce E, Dorantes H, Arellanes-Lozada P (2008) Mater ChemPhys 110(2-3):344

[14]. Barouni K, Bazzi L, Salghi R, Mihit M, Hammouti B, Albourine A, El Issami S (2008) Mater Lett 62(19):3325 [15]. Ismail KM (2007) ElectrochimActa 52(28):7811

[16].V. Shanmugapriya, C. Umarani, Int. J. Res. Eng. Sci., 2015, 3, 51-58.

[17]. A.N. Senthilkumar, K. Tharini, M.G. Sethuraman, Surface Rev. Lett., 2009, 16, 141. [18]. A.N. Senthilkumar, M.G. Sethuraman, Corros. Rev., 2008, 26, 23-37.

[19]. A.B. Silva, S.M.L. Agostinho, O.E. Barcia, G.G.O. Cordeiro, E. D’Elia, Corros. Sci. 48 (2006) 3668.

[20]. L. Toufari, A. Kadri, A. Khalifa, N. Aimeeur, N. Benbrahim, J. Eng. Appl. Sci. 3 (a) (2008) 688.

[21]. E.E. Oguzie, Y. Li, F.H. Wang, J. Electrochim. Acta 53 (2007) 909.

[22] X. He, J. Mao, Q. Ma, and Y. Tang, "Corrosion inhibition of perimidine derivatives for mild steel in acidic media: electrochemical and computational studies," Journal of Molecular Liquids, vol. 269, pp. 260-268, 2018.

[23] A. A. Mahmmod, I. A. Kazarinov, A. A. Khadom, and H. B. Mahood, "Experimental and theoretical studies of mild steel corrosion inhibition in phosphoric acid using tetrazoles derivatives," Journal of Bio- and TriboCorrosion, vol. 4, no. 4, p. 58, 2018.

[24] M. Messali, M. Larouj, H. Lgaz et al., "A new schiff base derivative as an effective corrosion inhibitor for mild steel in acidic media: experimental and computer simulations studies," Journal of Molecular Structure, vol. 1168, pp. 39-48, 2018.

[25] A. Mishra, C. Verma, S. Chauhan et al., "Characterization, and corrosion inhibition performance of 5-aminopyrazole carbonitriles towards mild steel acidic corrosion," Journal of Bio- and Tribo-Corrosion, vol. 4, p. $53,2018$.

[26] N. Saini, R. Kumar, H. Lgaz et al., "Minified dose of urispas drug as better corrosion constraint for soft steel in sulphuric acid solution," Journal of Molecular Liquids, vol. 269, pp. 371-380, 2018[27]. M. Yadav, S. Kumar, I. Bahadur, and D. Ramjugernath, "Electrochemical and quantum chemical studies on synthesized phenylazopyrimidone dyes as corrosion inhibitors for mild steel in a $15 \% \mathrm{HCl}$ solution," International Journal of Electrochemical Science, vol. 9, pp. 3928-3950, 2014.

[28]. P. Muthukrishnan, P. Prakash, B. Jeyaprabha, and K. Shankar, "Stigmasterol extracted from Ficushispida leaves as a green inhibitor for the mild steel corrosion in $1 \mathrm{M} \mathrm{HCl}$ solution,” Arabian Journal of Chemistry, 2015. 